Herger Csabáné

DOI: 10.15170/DIKE.2017.01.01.03

habilitált egyetemi docens

PTE ÁJK

\title{
Szakrális kontra szekuláris értékek a polgári modernizáció korában
}

\section{Sacral contra Secular Values in the Period of the Civil Modernization}

European legal culture is primarily rooted in Roman-Germanic heritage and Jewish-Christian revelation, although it is not intact from Asian and islamic effects. As opposed to the absolute values of the Jewish-Christian culture, from the time of the French Revolution relativism concerning good and bad, right and wrong is trendy. Absolute sacral values and relative secular values differentiated from each other only at the early time of the civil modernization. However when the public life passed into profane, became this distance only exceptional. The combination and rivalry of sacral and secular values are typical up to the present day in Europe.

Keywords: sacral values, secular values, civil modernization, Jewish-Christian legal culture

\section{Szembe állíthatók-e a polgári modernizáció korának szakrális és a szekuláris értékei?}

A modern állam az újkortól kezdődően a közélet formájára illetve az államélet egészére vonatkozó általános megjelölés. Maga a szó elsősorban időbeliséget fejez ki, a tartalma azonban ennél jóval összetettebb. Az összehasonlító alkotmánytörténet-tudomány módszereivel a modern állam fogalmát - annak lényegét tekintve - az alábbiak szerint lehet meghatározni.

Ha modern államról beszélünk, elsősorban arra a külöbségre gondolunk, amit a keleti, az antik és a középkori államokkal szemben ez megjelenít. Jellemző, hogy az állam kategóriát a legfiatalabb típustól, a modern államtól kölcsönözzük a régebbi típusok leírásához. Maga a modern állam három szakaszban formálódott ki. Az első stádiumban a korábbi, középkori hierarchikusfeudális államból a modern állam ideáltípusára jellemző vonulatok jelentek meg úgy, hogy sokáig még felismerhetők voltak a középkori vonások is. Ez a korai szakasz tehát a modern állam kiépítésének korszaka volt, amely időben a francia forradalomig, 1789-ig tartott. A második szakaszban már többnyire az ideáltípus teljessége érvényesült. Ezt nevezzük a modern állam virágkorának, ami lényegében a 19. századot ölelte fel. A harmadik szakaszban ezzel szemben már a leépülés nyomai tûntek fel, amikor is az ideáltípus újabb tendenciák megjelenésével lassan szétfoszlott. Ezzel tehát a modern állam időbeli határai nyilvánvalóvá váltak: a modern állam kifejezést a nyugati politikai és jogi kultúra területén a középkor végétől számítva a 20. század elejéig, többnyire az I. világháború végéig szokás alkalmazni.

A modern állam ideáltípusát úgy lehet megragadni, ha megvizsgáljuk ennek a három szakasznak azokat a tendenciáit, amelyek együttes hatása következtében a modern állam megjelent. Ezzel a módszerrel négy különböző absztrakció különíthető el, amelyek egymást kölcsönösen kiegészítették. Elsőként a szuverén abszolút állam jelent meg, majd a viszonylag kötött, polgári- 
kapitalista társadalmi és gazdasági formációval rendelkező ún. kereskedőállam. Ezeket harmadikként az individuum személyes szabadságának jelszavát hangsúlyozó liberális jogállam követte, majd a sort a nemzetállam zárta le az előző tendenciákat is átfogva, demokratikus irányultsággal. ${ }^{1}$

A polgári modernizáció korának értékeit vizsgálva - bár mind a négy absztrakciónak voltak karakterisztikus értékei - elsősorban a liberális jogállam jelentőségét kell kiemelni.

$\mathrm{Az}$ abszolút állammodell esetében a lényegi újdonság a világi hatalom teljességére vonatkozott. Egyrészt a szuverén abszolút állam az egyházi gyámkodás alól felszabadulva világi államként lépett a középkori monarchiák helyére, másrészt a hatalom teljessségét olyan értelemben is megjelenítette, hogy az uralkodó hatalma és felsőbbsége saját jogán alapult, szemben a nép által az uralkodóra átruházott hatalom elméletével, amely - római gyökerekből táplálkozva - a középkorban is jelen volt. Az állam ezzel kilépett a korábbi közösségi viszonyokból és önmaga meghatározójává vált. Ennek előfeltétele belülről az államhatalom kizárólagossága, kívülről pedig függetlensége volt.

A viszonylag kötött, polgári-kapitalista társadalmi és gazdasági formációval rendelkező ún. kereskedóállam a modern államnak a gazdasági életben betöltött helyét jelenítette meg, amelyben a föszerepet a merkantilizmus játszotta. A kapitalizmust nem az állam hozta létre, de az állammal kapcsolatban, annak szolgálatában és védelme alatt vált mértékadó gazdasági formává. Korai szakasza a merkantilista gazdaságpolitikával kezdődött el, míg virágkora egybeesett a modern állam virágkorával, azaz a 19. századdal. Kétség nélkül mondhatjuk tehát, hogy erôsen kötődött a modern államhoz és annak polgári társadalmi rendjéhez.

Az utolsóként megjelent absztrakció, a nemzetállam kollektív-szövetségi szerkezete a liberális jogállammal szemben abból adódott, hogy a nép egy egységet képezett és ez az egyesülés nem uralmi, hanem szövetségi formában történt meg. A nemzetállamok alapja az az összetartozásérzés volt, amely a közös származásból, nyelvből, kultúrából és történelmi emlékezetből táplálkozott, bár a kulturális nemzetállam helyett - amely csak nemzeti és etnikai kisebbségekkel nem rendelkező államban valósulhatott volna meg - az európai államokban rendszerint voltak (és vannak is) kisebbségek. Ennek következtében csakis a politikai nemzetfogalomnak lehetett realitása, amely szerint a hangsúly a nemzettel való azonsuláson, nem pedig a származáson volt.

A tanulmány tárgya szempontjából a modern állam ideáltípusának legfontosabb (időben többnyire harmadikként kibontakozó) absztrakciója az individuum személyes szabadságának jelszavával operáló liberális jogállam volt, amely nemcsak az objektív jogrend védelmezője, hanem az ember és a polgár szubjektív igényeinek őre is volt mind a magánszféra, mind a közélet területén. Eszköze a racionális törvényi jog volt, amely a 18-19. század fordulójára többnyire előtérbe került az eddigi szokásjoggal és bírói precedensjoggal szemben. A felvilágosult abszolutizmus már jogegységesítésbe fogott, melynek eredményei mellett a legisták recipiált római joga a monarchikus szuverenitás védelmezőjének bizonyult a forradalom elôtti Franciaországban illetve az alattvalók magánszférájának javát szolgálta a német térségben. Ezt követően az individualizált jogi racionalizmus termékeiként jelentek meg a nagy természetjogi kódexek, többek között a porosz ALR (1794) és francia Code Civil (1804). Ezzel egyidőben átalakult és egyben bürokratizálódott az

\footnotetext{
${ }^{1}$ A négy absztrakciót lásd bővebben HiNZE, Wesen und Wandlung 470-496.
} 
igazságszolgáltatási rendszer is. Fontos szólni az alattvalók szubjektív közjogi jogainak elismeréséről és védelméről is.

Ez a tendencia az angol polgári forradalommal vette kezdetét, majd az Amerikai Egyesült Államok alkotmányával (1787) és annak első tíz kiegészítésével (Bill of Rights 1791) teljesedett ki. A klasszikus szabadságjogokat ezek után minden modern alkotmány alapjogként ismerte el. A szabadságjogok mellett a polgári szabadság másik tartópillére a képviseleti alkotmány volt, amelyben az államhatalom különböző funkcióit a törvényhozó, a végrehajtó és az igazságszolgáltató hatalmat egymástól elválasztották. A jogállam mindezeket számba véve a jogcél megvalósítását, a törvények szerinti kormányzást jelentette és jelenti. A gyakorlatban azonban egyetlen kormányzat tevékenysége sem korlátozódhatott a törvények egyszerú végrehajtására, hiszen mindennapos jelenséggé vált, hogy a végrehajtó hatalomnak döntést kellett hozni. Ezért a pártalapú kormányok esetében feltétlen szükségesnek bizonyult az is, hogy e döntéshozatal ellenőrzésére független közigazgatási bíróságot intézményesítsenek. A liberális jogállam lényegét ezért - legyen szó alkotmányos monarchiáról vagy köztársaságról - abban látjuk, hogy az egyén védelmet élvez a rendőrséggel és a közigazgatási hatóságok aktusaival szemben.

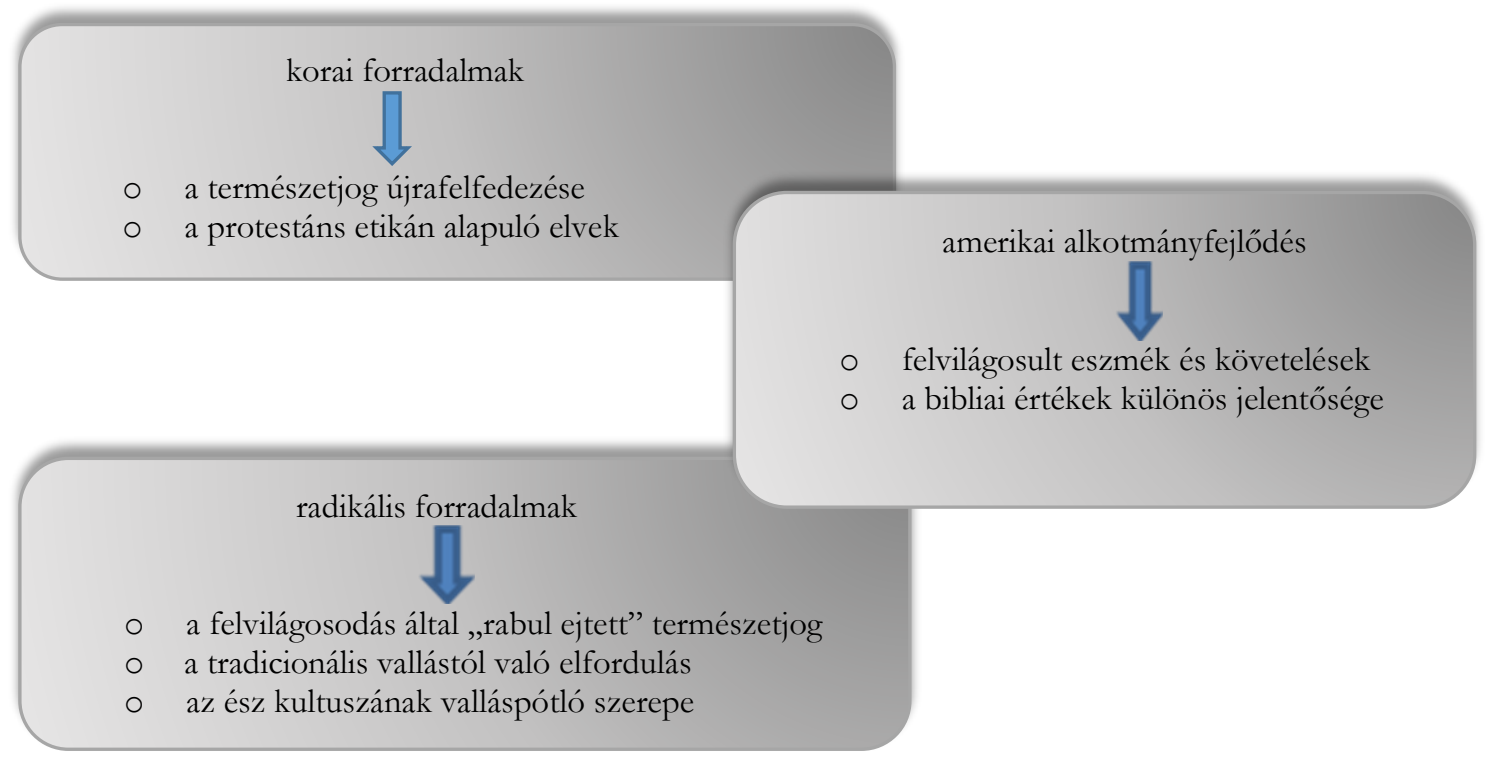

1. ábra: A polgári modernizáció eszmetörténeti modelljei

A modernizáció következő színhelye Anglia és az Amerikai Egyesült Államok után Franciaország volt, ahol 1789-ben a felvilágosodás által meghódított természetjog, az ún. észjog szolgáltatott ideológiai alapot a radikális forradalomhoz, az abszolutizmus felszámolásához és az Emberi és Polgári Jogi Nyilatkozat (1789) elveire hivatkozva a polgári jogegyenlőség elvén álló jogrendszer kiépítéséhez. Európa középső és keleti része csak jelentős késéssel, a 19. század derekán volt képes a modern polgári állam kiépítéséért harcba szállni, bár ekkor még német és osztrákmagyar területen is várni kellett az áttörésre: a német egység létrejötte (1871) illetve az osztrákmagyar kiegyezés (1867) volt az, ami megnyitotta az utat a modernizáció előtt. Ezek a polgári átalakulás és modernizáció szempontjából megkésett államok az eszméket túlnyomó részben nyugatról exportálták: a kor jogforrásai és a politikai irodalom tükrében egyértelmûen állítható, 
hogy a gondolkodók és politikusok „vigyázó szemüket” nemcsak Párizsra vetették, hanem az amerikai eredményekre is tekintettel voltak. Ennek következtében nem csak az elméleti múvekben, hanem a konkrét jogforrásokban is világosan kimutatható, hogy mikor használt a jogalkotó angol, amerikai, francia vagy más megoldást modellként illetve ezeket hogyan igazította hozzá az adott állam társadalmi viszonyaihoz és uralkodó értékfelfogásához. ${ }^{2}$

A fejezetcímben feltett kérdésre ezért a válasz nemleges: a szakrális és a szekuláris értékek csak a polgári modernizáció korai szakaszában különültek el világosan. A közélet világivá válását követôen ez a távolságtartás kivételessé vált, és többnyire csak a felekezetükhöz erősen kötôdő valamint annak hivatalos véleményét képviselő közéleti szereplőknél jelent meg. A jogforrásokban ekkor egyértelmű szembenállás már egyáltalán nem volt jellemző, csupán a keveredés kisebb vagy nagyobb mértékét lehet kimutatni.

\section{A szakrális és a szekuláris értékek párhuzamossága}

Az európai jogi kultúra zsidó-keresztény értékei körében Rezső́házy Rudolf az egyetemes értékek, a hívők közösségének értékei és a hívők közösségén túl terjedő értékek között tett különbséget. ${ }^{3}$ Kifejtette, hogy a zsidó-keresztény jogi kultúrában „megtaláljuk azokat az egyetemes normákat, amelyek minden nagy civilizációban föltünnek. Ezek az egyetemes normák minden társadalom alapját képezik. Így van ez. Mózes típparancsolatával. Az ebben fölsorolt értékeke nélkül a közösségi élet ellehetetlenülne: az élet védelme (ne ölj), a tulajdon fontossága (ne lopj), a család és a más élettársának tisztelete, a nemi ösztön szabályozása. Ezeket az általános érvényü elveket példázza a bíres aranyszabály is: Ne tedd másokeal azt, amit nem szeretnél, hogy veled tegyenek. Másrészt vannak tipikusan keresz̨tény és csak az evangéliumokban található értékek. Amikor Jézus arra bivja tanitványait, hogy legyenek tökéletesek, mint abogy mennyei Atyánk tökéletes, mély bivönek. kell lenni ahboz, hogy valaki ebhez az ideálhoz. közeledjék. Amikor a kapott ütés után a másik orcát kell nyújtani, csake a bit adhat bátorságot abhoz, hogy az ember igy cselekedjék. Szeresd ellenségeidet - ime egy magatartás, mely meghaladja az átlag egyén erejét. A hegyi beszéd által ajánlott erények ellentétesek a közvélemény által elfogadott szokéasokkal: a szegénység, a szelidség, a könnyek, az igazságra vágyás, az irgalom, a jósziviuség, a békee.

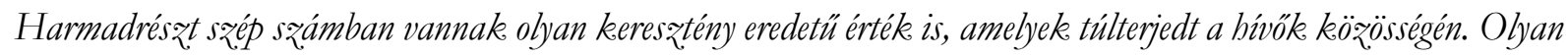
általános európai értékeekeé lettek, melyeket mindenki elfogad, legyen az bivó, bitetlen, agnosz̨tikus, közömbös vagy akár a vallás ellensége. Még egy európai ateista is európai módon tagadja Istent." 4

Bár Rezsoóháay negyvenhét értéket vizsgált a fenti hármas csoportosítás szerint, az alábbiakban (a teljesség igénye nélkül) csak az európai jogfejlődés szempontjából különösen fontos értékekről lesz szó, melyek a polgári modernizáció korában jellemzően a zsidó-keresztény kultúrához kötődő természetjogi felfogás értékkatalógusában és a szekularizált szemléletet tükröző felvilágosult észjogi értékkatalógusban is megjelentek, bár különböző elméleti indokolással, de többnyire azonos lényeges tartalommal. Ezek az emberi méltóság fogalma, a jogegyenlőség elve valamint a szabadságeszmény és ennek következtében a tolerancia követelménye.

\footnotetext{
${ }^{2}$ KAjtÁr - Herger, Egyetemes állam- és jogtörténet 133-149.

${ }^{3}$ Herger, A megélt kor 95.

${ }^{4}$ Herger, A megélt kor 95.
} 


\subsection{Az emberi méltóság}

Az emberi jogok első generációjaként megjelent klasszikus szabadságjogok alapját az emberi méltóság (dignitas humana) képezi. Az élőlények között egyedül az ember rendelkezik hármas, testilelki-szellemi integritással, ami személlyé teszi. A személy képes arra, hogy életét saját belátása szerint, értelmével maga határozza meg és alakítsa. A személy méltósága az emberiség történetében elsőként a zsidó vallásfilozófiában jelent meg azzal, hogy a ius Divinum a szabad akarattal, Isten képére teremtett emberiség minden tagját méltósággal ruházta fel. ${ }^{5} \mathrm{~A}$ görög szofisták is egységes csoportként értelmezték az emberiséget: egyrészt azt állították, hogy a természetjog szerint nincs különbség ember és ember között, másrészt úgy gondolták, hogy ha a valóságban mégis létrejött bármiféle különbség, az csak erôszak és hatalom következménye lehet. Arisztotelész. ezzel szemben azt állította, hogy természettôl fogva vannak szabadok és szolgák, és a szolgaság ez utóbbiak esetében hasznos és jogos. Jusztinianosz mintegy 800 évvel később úgy vélte, hogy az emberek szabadon születnek és a rabszolgaság ellentétes a természetes renddel - bár ez utóbbi intézményt a jusz̧tinianosz̨i jog sem számolta fel. A középkori egyházjogba az emberi méltóság fogalma a zsidó vallásfilozófiából került át.

Aquinói Szent Tamás azt állította, hogy Isten elôtt minden ember egyenlő és Isten országának polgáraként veleszületett méltóság hordozója, ez a méltóság pedig elidegeníthetetlen és sérthetetlen értékként természetes korlát a világi hatalom minden beavatkozásával szemben. Az emberi méltóság fogalmát a teológiából a világi jogtudományba a humanista Pico della Mirandola exportálta. Ezzel az emberi méltóság az ember személyiségének központi részeként az ember és az állam közötti viszonyban kulcsfogalommá vált. ${ }^{6} \mathrm{Az}$ európai jogtudományban a személy ontológiai adottságának elismerése számottevő mértékben az újkor kezdetén jelent meg. Ezzel az embert a közösség tagjaként megillető jogok és kötelezettségek háttérbe tolódtak (szekunder szerep), míg az embert egyénként megillető jogok és kötelezettségek elsődleges értelmet (primer szerep) nyertek.7 Az emberi méltóság ekkortól kezdve mindenkor az emberi jogok alapját képezte és képezi, bár a polgári modernizáció korának jognyilatkozataiban illetve alkotmányos dokumentumaiban maga az emberi méltóság kifejezés jellemzően nem szerepel.

Különösen fontos az amerikai Bill of Rights (1791), azaz az Amerikai Egyesült Államok alkotmányának (1787) első tíz kiegészítése, melyek közül a IX. cikkelyben rögzített generális klauzula szerint a Bill of Rights jogkatalógusa nem taxatív felsorolás, hanem azt a „nép által élvezett jogok" egészítik ki, melyek (többek között az emberi méltóság, a becsülethez vagy amagánélethez való jog) a commmon law alapján védendők, akár a konkrétan nevesített jogokkal szemben is. ${ }^{8} \mathrm{~A}$ dignitas bumana fogalmát korunk Európája a zsidó-keresztény jogi kultúrából (kánonjogi közvetítéssel) örökölte. Ezt tagadni felesleges, de egyben lehetetlen is.

\footnotetext{
${ }^{5}$ I Mózes 1:7, 26

${ }^{6}$ HaLmai, Az emberi jogok igazolása 20-37.

${ }^{7}$ NiETLISPACH, Grundlagen der Freiheitsrechte 9.

${ }^{8} \mathrm{http}: / /$ www.verfassungen.net/us/verf87-i.htm
} 


\subsection{A jogegyenlőség elve}

A szabadságjogok érvényesülési feltételei között a liberális jogállam elméleti megfogalmazói a jogegyenlőség elvét és az ún. negatív szabadság fogalmát jelölték meg. Ez utóbbi John Stuart Mill (1806-1873) szerint azt jelenti, hogy az állam kényszert állampolgáraival szemben egyetlen esetben alkalmazhat csak: akkor, ha ez más állampolgár jogsérelmének a megakadályozását szolgálja. Ahogy ezt az Emberi és Polgári Jogi Nyilatkozat már megfogalmazta: „A szabadság abban áll, hogy mindent megtehetünk, ami másnak sem árt, igy tehát minden ember természetes jogainak gyakorlása csak olyan korlátba ütközhet, amelyek a társadalom más tagjainak biztositják, hogy ugyanezekekel a jogokkal élhessenek. Ezeket a korlátokat csak a törvény állapithatja meg." (IV. cikkely) ${ }^{9}$ Ezek szerint a szabadság (liberalizmus) és a szabadosság (libertianizmus) élesen elkülönül egymástól. Míg az utóbbi korlátnélküliséget jelent, addig a szabadságnak van határa, hiszen addig terjedhet csak, amíg más ember jogát nem sérti. A Nyilatkozat szerint a törvények feladata ezeknek a korlátoknak a meghatározása (V. cikkely), tehát a nemzetszuverenitás elvén álló törvényhozó hatalom jogosult egyedül arra, hogy ezt megtegye (VI. cikkely). Mindehhez hozzátartozik az is, hogy a Nyilatkozat rögzítette: amit a törvény kifejezetten nem tilt, az szabad (V. cikkely). Francia mintára ez az elv az Elbától nyugatra a polgári modernizációval általánossá vált, míg az Elbától keletre ennek ellentéteként az ún. autokratilus jogelv még hosszú ideig továbbélt, azaz amit a törvény kifejezetten nem engedett meg, azt tilosként fogadták el. ${ }^{10}$

A polgári jogrendszer kiépítésére az egyes államokban akkor került sor, amikor a modern államépítési alapelvek a gyakorlatban már érvényesültek és lehetőséget biztosítottak a jogrendszer fejlesztéséhez. Ennek általános menete az addigi jogi partikularizmus felszámolásával az egységes jogrend megteremtése volt. Joggal nevezhetjük ezért a polgári korszakot a jogfejlődés tekintetében a kodifikációk korának - legalábbis a kontinentális jog területén. Mivel a középkori illetve feudális jogban a nyílt jogegyenlőtlenség elsősorban a társadalmi állás, ezen túl pedig a nemi és vallási hovatartozás következtében a magánjogban, a büntetőjogban és kisebb mértékben az eljárásjogok területén is megjelent, polgári jogrend kiépítésére csakis úgy kerülhetett sor, hogy ezeket a különbségeket felszámolták.

A modern államépítési elvek körében a jogtudomány a jogegyenlőséget a klasszikus szabadságjogok érvényesülési feltételeként értelmezte és értelmezi, ez azonban az alkotmányjogon túl a többi jogág területén is igaz: a jogegyenlőség abból fakad, hogy minden embert emberi méltóság illet meg és ugyanazokkal a jogokkal jön világra, ez pedig kizár minden társadalmi állásra, nemre, vallásra, etnikai hovatartozásra vagy más tényezőre alapozott jogszabályi diszkriminációt. $\mathrm{Az}$ amerikai Függetlenségi Nyilatkozat ezt így fogalmazta meg: „Mi equeket az igazságokat magától érthetönek tartjuk, hogy minden ember egyenlönek van teremtve". A francia Emberi és Polgári Jogi Nyilatkozat ezzel szemben azt hangsúlyozta, hogy minden ember „szabadnak és egyenlönek sqületik”. ${ }^{11} \mathrm{Ez}$ a különbség csak a két nyilatkozat eltérő eszmetörténeti hátterére utalt, a lényeg azonban ugyan az volt: a teljes diszkriminációtilalom.

Anélkül, hogy a modern eljárásjogi elvek között a jogegyenlőség elvét a modernizáció-kori

\footnotetext{
${ }^{9}$ Mika Sándor fordításában lásd http://mek.oszk.hu/00000/00056/html/228.htm

${ }^{10}$ PÉTER, Volt-e magyar társadalom 5-8.

${ }^{11} \mathrm{http}: / /$ www.verfassungen.net/us/index.htm
} 
jognyilatkozatok és kódexek expressis verbis nevesítették volna, a formális jogegyenlőségnek az eljárásjogi szabályokban is érvényesülnie kellett és kell, ahhoz, hogy azok értelmezhetőek legyenek. A magánjogi és büntetőjogi természetjogi kódexekben azonban kifejezetten megjelent a jogegyenlőség követelménye, és a részletszabályokban is törekedtek annak érvényesítésére. Ezt azonban - többnyire a tradicionális gyökerek maradandósága miatt - nem feltétlenül sikerült megvalósítani.

A magánjog területén hosszan sorolhatnánk a jogegyenlőség elvével szembeni hiányosságokat a bajor CMBC-ben (1756), a porosz ALR-ben (1794), az osztrák OPTK-ban (1812) és a Code Civil-ben (1804), de a következetes megoldással a kodifikáció második hullámához tartozó pandektista törvénykönyvek is adósok maradtak. Így a munkaadó és a munkavállaló közötti jogviszony kellő szabályozása, a női jogegyenlősítés (elsősorban a házas nô személyi és vagyoni jogi önállóságának kérdése) és a házasságon kívül született gyermekek hátrányos helyzetének a felszámolása is a 20. századra, többnyire annak második felére maradt. Sajátos, hogy a középkori jogban az izraelita vallás a jogképességet és a cselekvőképességet is befolyásoló tényező volt, de a polgári modernizáció korának természetjogi kódexei sem feltétlenül valósították meg a zsidók polgári jogegyenlősítését. A francia forradalmi-kori emancipációval szemben az Elbáttól Keletre a reformkorban kezdődő, lépcsőzetes jogkiterjesztés történt (amit a polgári demokráciák leépülésének korában, a két világháború közötti időszakban a fokozatos jogkorlátozás, majd jogfosztás követett). Míg ez igaz az osztrák örökös tartományok zsidó lakosságára is, az OPTK személyi jogi része - a bécsi udvar elkötelezett felvilágosult természetjogászainak, elsősorban Sonnenfelsnek, majd később Zeillernek köszönhetően - 1812-ben már rögzítette, hogy az állam területére lépő rabszolga ipso iure felszabadul. ${ }^{12}$ Tegyük hozzá, rabszolgája nem igen akadt a gyarmatokkal nem rendelkező Habsburg Birodalomnak, így könnyen tehetett - a felvilágosult elveknek megfelelő - gesztust, miközben a saját problémáit nem tudta megoldani.

A rabszolgák jogalannyá válása (állampolgárság kérdésén és a politikai jogegyenlősítésen túl a polgári jogi jogegyenlősítés) azért kulcsfontosságú a modern államok történetében, mert ennek a területnek a modernizálásával sokáig adósak maradtak egyes államok: az olcsó munkaerőhöz fűződő gazdasági érdek és a faji előítélet felülírta a szabadság és a jogegyenlőség iránt elkötelezett társadalmak illetve a gazdasági-politikai elit szándékait. A néger rabszolga-kereskedelem megszüntetése és a rabszolgamunkaerő alkalmazása a különböző területeken több szakaszban, hosszabb idő alatt valósult meg. Angliában 1807-ben, az angol gyarmatokon pedig 1830-ban szabadították fel a rabszolgákat. Annak ellenére, hogy Franciaországban a jakobinus többségú nemzetgyúlés 1794-ben megszavazta a rabszolgaság felszámolását, XIV. Lajos ordonnance-a, az ún. Fekete kódex 1685-től 1848-ig hatályban maradt. Így tehát a francia gyarmatokon csak 1848-ban szűnt meg a rabszolgaság mintegy 244 ezer fekete bőrű ember felszabadításával. Ezt követően az Amerikai Egyesült Államokban alkotmányos úton 1865-ben, Brazíliában 1871-ben, Kubában pedig csak 1880-ban került sor arra, hogy a volt rabszolgák dologból személlyé, jogalannyá válhassanak a pozitív jog szerint, mint ahogy addig is azok voltak a természetjog szerint. Afrika belsô részein azonban ezt követően is tevékenykedtek a rabszolgavadászok és rabszolga-kereskedők, akikkel maguk a törzsfők is kötöttek adásvételi üzleteket a más törzsből kikerülő hadifoglyokról és saját

\footnotetext{
12 OGRIS, Josepf Sonnenfels 110.
} 
törzsük egy részéről is. Ezeket az állapotokat 1890-ben Brüsszelben nemzetközi jogi egyezmény kívánta felszámolni, bár az emberkereskedelem rejtett formái továbbra is megmaradtak.

A jogegyenlőség biztosítása a modern büntetőjogban is alapvető célkitűzésként jelent meg: a büntethetőség feltételei, az eljáró bíróságok hatásköri szabályai, a büntetés mértéke vagy a büntetés-végrehajtás nem függhet a társadalmi állástól, nemtől vagy egyéb tényezôtől, mind emellett vannak olyan személycsoportok, amelyekre saját büntető anyagi, eljárási és végrehajtási szabályok vonatkoznak. Ilyenek a fiatalkorúak és a katonai bíróságok előtt elbírálandó személyek ügyei.

A természetjog és a felvilágosodás természetesen a büntetőjog-tudományt is megtermékenyítette. A jogegyenlőség biztosítása nélkül a modern büntetőjog többi elve értelmezhetetlen, azaz azok alapját képezi. Amikor Joseph von Sonnenfels, Mária Terézia udvari jogásza kifejtette, hogy a bűncselekményeket pontos törvényi tényállásban kell rögzíteni, ez már nem volt előzmény nélküli törekvés: az újkortól kezdve számos jogforrásban törekedtek a büntetendő magatartások pontos meghatározására, ahogy azt a német birodalmi Carolina (1532), XIV. Lajos büntető ordonnance-a (1670) vagy az alsó-ausztriai Ferdiandea (1650) is jelzi. Sonnenfels múvével egy időben (1764) jelent meg Cesare Beccaria itáliai büntetőjogász rövidke műve „A bűncselekményekről és a büntetésekről” címmel, melyben tételszerủen rögzítette azt, amit más szóhasználattal Sonnenfels is megfogalmazott. A nullum crimen sine lege elv érvényesülése kizárja azt, hogy a büntető igazságszolgáltatás a végrehajtó hatalom önkényes befolyása alá kerüljön. Beccaria célja a büntetőjog modernizálása, az önkény és a kegyetlenség elleni küzdelem volt, ahogyan Sonnenfels is - nem kis kockázatot vállalva - ez ellen szólalt fel Bécsben. Mária Terézia büntető törvénykönyve, a Constitutio Criminalis Theresiana (1768) alkalmazta a bűncselekmények törvényi meghatározásának követelményét, amely szerepelt a francia Emberi és Polgári Jogi Nyilatkozatban is, majd ezt követően általánossá vált a modern büntetőjogi kódexekben. Jellemző módon a polgári demokráciák értékeit kétségbe vonó államokban írták csak felül, mint többek között a francia jakobinus diktatúra idején, a náci jogrendben az ún. egészséges népi érzület kategóriájával, illetve a kommunista Szovjetunióban a dolgozó nép ellensége kitétellel. A nullum crimen sine lege elv értelmezéséhez hozzátartozik az is, hogy pontosan meghatározzuk, mikor keletkezett az a jogszabály, amely alapján a felelősségre vonás történik. Az Emberi és Polgári Jogi Nyilatkozat előírta, hogy mindenkit csak olyan törvény alapján lehet megbüntetni, amelyeket a bűncselekmény elkövetése előtt hoztak és hirdettek ki, és ezzel a kontinentális büntetőjogban a későbbiekben általánossá vált a visszaható hatály tilalma.

Éppen így a jogegyenlőség elve köszön vissza közvetett módon a büntetések (nemének és mértékének) törvényhez kötöttségében is (nulla poena sine lege), bár a forradalmi korszak abszolút határozott, szigorú büntetési rendszerét, amelynél a jogalkotó a bíró mérlegelési lehetôséget kizárta, a gyakorlati tapasztalatra hivatkozva két évtized múlva Napóleon büntető törvénykönyvében (Code Pénal, 1810) már felülírták. A modern büntetőjogi elvek közé sorolt analógia-tilalmat az angolszász jog területén a common law büntetôjog léte miatt nem találjuk meg, és szó szerint ugyan az Emberi és Polgári Jogi Nyilatkozat sem rögzítette. A büntetőjogra vonatkozó cikkelyei azonban tiltották az önkényes ítélkezést, valamint a nem törvény alapján történő ítélkezést, azaz az analógia alkalmazását és a szokásjog alapján történő eljárást is.

A modern büntetőjog elvei különösen rávilágítanak arra a fontos tényre, hogy ezek érvényesülése a gyakorlatban csak akkor lehetséges, ha az államépítési alapelvek biztosítják ehhez a feltételeket. E három utóbbi jogelv a törvények uralma államépítési elvben kapcsolódott egybe, és 
rendszerint együtt jelent meg a modern büntetőkódexekben. A modern büntetőjoghoz köthető a humanizmus elve is, melynek az anyagi jogi szabályokban, az eljárásban és a végrehajtásban is érvényesülnie kell. Sonnenfels és Beccaria egyaránt hangsúlyozta, hogy a büntetéseknek nem kegyetlennek, hanem az okozott sérelem nagyságával egyezőnek kell lennie, és a bűnüldözés hatékonysága nem a büntetőtörvények szigorából, hanem a felelősségre vonás elkerülhetetlenségéből fakad. Az önkényes jogalkalmazás pedig mindezt gátolja. Mindketten felléptek a tortúra alkalmazása és a halálbüntetés ellen is. Az angol Bill of Rights 1689-ben már rögzítette a kegyetlen és szokatlan büntetések tilalmát, majd erre a jogi tradícióra alapítva az amerikai Bill of Rights körében is helyt kapott ugyanez az elv 1791-ben. Az Emberi és Polgári Jogi Nyilatkozat erre a felvilágosult, természetjogi alapú felfogásra hivatkozva rögzítette, hogy „meg kell büntetni azokat, akik önkényes intézkedéseket szorgalmaznak, hoznak, végrehajtanak vagy végrehajtatnak", illetve „a törvény csak nyilvánvalóan szü̈kséges büntetéseket szabhat ki” (VII. és VIII. cikkely).

Mindezekkel szemben fontos felhívni a figyelmet arra a tényre, hogy a jogegyenlőség elve - az alkotmányjoghoz és a magánjoghoz hasonlóan - a büntetőjogban sem érvényesült feltétlenül a polgári modernizáció korában sem. Hogy csak a legfontosabb példákat nevesítsük, amíg a rabszolgaság intézménye létezett, amíg a zsidók polgári jogegyenlősítése késlekedett, amíg a női emancipáció részleges maradt, ezek hatása minden jogágban jelentkezett. Az egyes európai államok fejlődésében ezen kívül jelelentős időbeli és a modernizáció melletti elkötelezettség tekintetében politikai különbség is volt.

\subsection{A szabadságeszmény és a tolerancia követelménye}

A szabadságjogok történeti megjelenésének és kiteljesedésének különböző korszakokhoz köthető Európában. A középkorban a szabadságokat illetve mentességeket, azaz a kivételes jogállást privilégiumok formájában biztosítottak egy adott személynek vagy személycsoportnak a magánjog, a hủbéri jog, a büntetőjog vagy a feudális közjog területén. ${ }^{13}$ Ilyen előzmények után a jogegyenlőség elvére alapított, minden embert egyaránt megillető szabadságjogok a 16. század végétől, illetve a 17. században a polgári átalakulás és modernizáció úttörőinél, észak-németalföldi területen és Angliában természetjogi indokolással jelentek meg. Az elméletet többek között Donellus, Grotius és Althusius alkotta meg. A hugenotta Donellus a személyt megillető élethez, testi sérthetetlenséghez és közéleti megjelenéshez való jogról beszélt, Grotius az emberi jogok elidegeníthetetlenségét hangsúlyozta, Althusius pedig a jogegyenlőségről értekezett. ${ }^{14}$

A protestáns etikán alapuló természetjogot az angol szigetország majdhogynem készen vette át tôlük a puritán forradalom során. Az eredményt ebben a korszakban a rendi Magna Carta Libertatumra hivatkozva a Petition of Rights (1628), a Habeas Corpus Act (1679) és a Bill of Rights (1689) rögzítette. Ez utóbbi törvény - a tradíciókból táplálkozó angol modernizáció részeként - az angol alattvalók jogait valóságos, ősi és kétségbe vonhatatlan jogként értelmezte. Annak ellenére, hogy ezzel bizonyos mértékben a szabadságjogok pozitivizált joggá váltak, összességében csak az

\footnotetext{
${ }^{13}$ KELLER, Freiheitsgarantien 7.

${ }^{14}$ HaLmai, Az emberi jogok igazolása 20-37.
} 
alapjogok előjogaina tekinthetők, mivel a királyi hatolom korlátjaiként, rendi jelleggel fogalmazták meg őket. ${ }^{15}$

A szabadságjogok átfogó pozitivizálása az amerikai, illetve francia jogfejlődésben valósult meg. Ennek alapvető dokumentumai az USA-ban a Függetlenségi Nyilatkozat (1776) ${ }^{16}$ valamint a szövetségi alkotmány első tíz kiegészítését tartalmazó Bill of Rights (1791), Franciaországban az Emberi és Polgári Jogi Nyilatkozat (1789) voltak. A szabadságjogokat az amerikaiak a Teremtótól származó, veleszületett és elidegeníthetetlen jogokként, a franciák természetes, elidegeníthetetlen és megszentelt jogokként értelmezték. Ezek a klasszikus szabadságjogokat tartalmazó dokumentumok a politikai társulások célját abban látták, hogy a polgárok számára a jogaikat biztosítsák. Könyvtárnyi irodalom foglalkozik azzal a kérdéssel, hogy az amerikai vagy a francia dokumentumok tekinthetők nagyobb hatásúnak. Minden részletezés nélkül ehelyütt csak annyit jegyeznénk meg, hogy az amerikai Bill of Rights valódi jogvédelmet biztosított, hiszen alkotmányos jog sérelme esetén az állampolgár bírósághoz fordulhatott, míg az Emberi és Polgári Jogi Nyilatkozat csupán egy államcélokat tartalmazó deklaráció volt. Eszmetörténeti jelentősége azonban mindkettőnek hatalmas nem csak Európában, hanem az Európán kívüli polgári modernizáció tekintetében is.

Természetesen nem hiba nélküli egyik dokumentum sem. A politikai és társadalmi környezet hatására jó példa, hogy az újszülött Amerikai Egyesült Államokban a philadelphiai alkotmányozó konvenció az alkotmány törzsszövegéből lényegét tekintve kihagyta az emberi jogokat. ${ }^{17}$ Úgylátták jónak, hogy a szabadságok alkotmányi rögzítése nyugodtabb időkre maradjon annak ellenére is, hogy a többségi zsarnokság elkerülésének fontos eszközét látták bennük, hiszen a többségi akarattal szemben a kisebbség ezekkel az egyéni és kollektív szabadságjogokkal élve fejtheti ki kellő módon véleményét. 1789 nyarán a föderalisták az alkotmányos intézményrendszer stabilizációja érdekében a korabeli emberi jogi felfogásnak megfelelően terjesztették elő a klasszikus szabadságjogokat tartalmazó katalógusukat. A Bill of Rights, amely a ratifikációt követően 1791. december 15-én lépett hatályba, csupán egy rövid felsorolás volt, melynek értelmezése a szövetségi Legfelső Bíróságra várt. Ez a folyamat ma sem lezárt. Alakulásában jelentős szerepet töltenek be a „tisðtesség fejlódő követelményel” („,the evolving standards of decency”), azaz a közösségi értékszemlélet változása.

Az eszmény és a valóság közötti szakadékot jelzi, hogy a Bill of Rights rendelkezései a szövetségi törvényhozó hatalom, a Kongresszus irányába jelentettek kötelezettséget, azaz a X. cikkely értelmében a tagállamok igen szigorú törvényeket hoztak a szabadságjogok területén ott, ahol a szövetségi hatáskör hiánya ezt lehetôvé tette. Ezért 1868-ban újabb alkotmánykiegészítésben (XIV. cikkely 1. \) döntöttek arról, hogy egyetlen állam sem hozhat vagy alkalmazhat olyan törvényt, amely korlátozza az Egyesült Államok polgárait megillető jogokat. Így a tagállamok és az unió közötti kapcsolat egyes vonatkozásainak rendezése kapcsán a Bill of Rightsban deklarált jogok

\footnotetext{
${ }^{15}$ Lásd bővebben KAJTÁR - HERGER, Egyetemes állam- és jogtörténet 164-172.

16 http://www.verfassungen.net/us/index.htm

${ }^{17}$ Pár apró szabályt rögzítettek csak. Ilyen az elnök szabadsága arra, hogy eldöntse, szekuláris vagy a szakrális esküt tesz-e hivatalba lépésekor (II. cikkely 1. §), az a szabály, hogy - az európai, illetve gyarmati tradícióval szemben - az Egyesült Államok joghatósága alá tartozó hivatali tisztség vagy megbízás betöltésével kapcsolatban nem lehet vallási hovatartozást megkövetelni (VI. cikkely), vagy az angol jogi tradícióval magyarázható Habeas Corpushoz való jog és a bill of attainder tilalma (I. cikkely 9.\$).
} 
az utóbbi cikkely védelme alá kerültek. Ennek értelmében az alkotmányos jogok - nagyjából száz év alatt - a tagállami jogokban is érvényesüléshez jutottak. Minden esetre a négy ízben (1868, 1880, 1886, 1892) is angol miniszterelnökké választott liberális William Gladstone az amerikai alkotmányt az emberi elme és szándék által valaha alkotott legcsodálatosabb múnek nevezte. Ha ez a megállapítás némiképp túlzónak is tünik, kifejezi, hogy az amerikai modell demokrácia iránti elkötelezettségével és intézményeivel közvetve vagy közvetlenül befolyásolta számos európai és Európán kívüli állam polgári modernizációs törekvéseit is.

Az Emberi és Polgári Jogi Nyilatkozatba foglalt jogokat a francia alkotmányfejlődés egyes, néha igen mozgalmas szakaszaiban a politikai környezetnek megfelelően értelmezték és használták fel a politikusok érvelésük során. Így az 1791-es alkotmány teljes egészében átvette a deklaráció szövegét, annak elejére került beillesztésre. Az 1793-as ún. jakobinus alkotmány pedig (amely egyébként nem lépett hatályba) az egyenlőség irányában fejlesztette tovább. Az 1795-ös alapdokumentum visszatért az 1789-es eredeti forrásokhoz, azonban már a francia polgár kötelességeiről is megemlékezett. A Napóleon nevéhez fűződő politikai rendszerek (a konzulátus, majd a császárság) érthető módon nem állították politikai és közjogi nyilatkozataik kirakatába a deklarációt és nem is azonosultak elveivel. A 19. század közepén a jogok alkotmányos rögzítése után az aktuális történelmi tapasztalatoknak megfelelően beillesztették azt az óvatos záradékot, hogy az adott jogokat a törvény korlátozhatja, a bonapartizmus több kiadást megért politikai rendszereinek idején pedig ilyenfajta katalógust az alkotmányos dokumentumok között hiába is keresünk. A 19. század alkotmányaiban szerepe halványabbá vált, míg a második császárság idejében Bonaparte Lajos politikai boszorkánykonyhájában már csak formálisan tisztelt, de nem alkalmazott jogtörténeti emlékké változott. Az 1880-as évek liberális refomhulláma során a szabadságjogokat újra a francia forradalmi hagyományoknak és felvilágosult eszméknek megfelelően szabályozták illetve pontosították, majd a századforduló éveiben lezajlott az egyház és az állam következetes szétválasztása is, bár ebben a köztársasági hagyományok ateista és antiklerikális elemekkel párosultak. A jogok és szabadságok katalógusát magában foglaló deklaráció a későbbiek folyamán szinte standard közjogi múfajjá vált. Ennek keretében a német nép alapjogairól szóló (1849-es) nyilatkozat mellett a 20. század közepén hivatkozhatunk az Emberi Jogok Amerikai Nyilatkozatára (1948) vagy az Emberi Jogok Egyetemes Nyilatkozatára, amely 1948-ban az ENSZ égisze alatt jött létre, majd 1966-ban kiegészült a Polgári és Politikai Jogok Nemzetközi Egyezségokmányával valamint a Gazdasági, Szociális és Kulturális Jogok Nemzetköri Egyezségokmányával.18

\section{Következtetések}

Egységes értékfelfogás Európában soha sem volt és bizonyára soha nem is lesz. Míg a korai polgári forradalmak időszakában az újra felfedezett természetjog és a bibliai gyökerű, protestáns etikán alapuló elvek domináltak az alkotmányos dokumentumokban, a felvilágosult észjog elvei és a tradicionális vallással szembeni merev ellenállás a nagy francia forradalom korától meghatározóvá vált. A 18-19. század fordulójától a szekuláris gondolkodásmód előretörése mellett is maradt azonban némi szerepe a zsidó-keresztény jogi kultúrára visszavezethető értékeknek, amelyek az

\footnotetext{
${ }^{18}$ Kajtár - Herger, Egyetemes állam- és jogtörténet 219. és 231.
} 
egyes európai államokban korszakonként eltérő intenzitással álltak és állnak a politikai és jogalkotói döntések mögött azok indokolásaként.

\section{Felhasznált irodalom}

ALEXY, Robert: Theorie der Grundrechte. Frankfurt am Main 1986

ADAMS, John: Értekezés a kánonjogról és a feudális jogról. In: LÉVAI Csaba (válogatta, fordította, szerkesztette és a jegyzeteket készítette): Új rend egy új világban. Dokumentumok az amerikai politikai gondolkodás korai történetéhez. Debrecen 1997, 3-24.

HALMAI Gábor: Az emberi jogok igazolása. In: TALLÁr Ferenc (szerk.): Az emberi jogok és az európai tradíció. Budapest 2002, 20-37.

HERGER Csabáné - KAJTÁR István (szerk.): Jogtörténészportrék I. Werner Ogris. Budapest-Pécs 2007

HERGER Csabáné - KAJTÁR István: Egyetemes állam- és jogtörténet. Budapest - Pécs 2015

HINZE, Otto, Wesen und Wandlung des modernen Staats. In: Staat und Verfassung. Gesammelte Abhandlungen zu allgemeinen Verfassungsgeschichte. Göttingen 1962, 470-497.

HUBER, Ernst Rudolf: Bedeutungswandel der Grundrechte. Archiv des öffentlichen Rechts 1933/62 1-98.

KELLER, Robert von: Freiheitsgarantien von Person und Eigentum im Mitelalter. Heidelberg 1933

MILL, John Stuart: A szabadságról. Budapest 1980

NiETLISPACH, Fritz: Grundlagen der Freiheitsrechte. Zürich 1977

PÉTER László: Volt-e magyar társadalom a XIX. században? Valóság 1989/5. sz. 5-8. 